\title{
Cultural Capital as Analytical Category: BeTWEen ECONOMY AND CULTURE
}

\section{Barbara Markowska*}

\section{Abstract}

The article considers relations between economy and culture focusing on the concept of cultural capital. I discuss different uses of the notion of capital as an analytical category in the discourse of social sciences. Then, I analyze Pierre Bourdieu's concept of cultural capital in the context of its specific interplay with Marx's heritage. The main thesis of this text is the claim that both of them used capital in extra-economical meaning and cultural capital in Bourdieu's theory is nothing more (and nothing less) then symbolic capital. Moreover, the argumentation shows that a basic Marxist dichotomy between economic and cultural causes (base/superstructure) becomes nowadays irrelevant.

Keywords: cultural capital, symbolic capital, Marx, Bourdieu

\footnotetext{
*Barbara Markowska, Ph.D., Collegium Civitas, Warsaw, Poland, e-mail: bmarkowska@civitas.edu.pl ORCID: https://orcid.org/0000-0002-9824-0453
} 
Introduction

For many years, a category of cultural capital has remained one of the most important elements of analysis allowing us to grasp and to describe the production and maintenance of social inequalities (Lamont, Lareau 1988; Moore 2008; Bennett et al. 2009; Silva, Warde 2010). Moreover, it indicates the relationship between two seemingly distinct reality spheres: economy and culture. We can capture their mutual influence in common known slogans repeated often without reflection like: "culture matters" or "culture counts". Particularly, the latter discloses a substantial ambivalence: culture counts because it signifies some values which are important to us and provides us with a sense of the world. Hence researchers claim that some constellations of cultural values - more than others - foster the wealth of societies and convert directly into economic profit (see: Harrison, Huntington 2000; Zelizer 2011). This claim functions in discourse with equally common conviction saying that formerly separated spheres of reality such as the science, or art (or more generally, the field of autonomous values) are now dominated by the process of economization and marketization (Çalışkan, Callon 2009).

In this article, we attempt to consider relations between economy and culture in light of the aforementioned discussions. Therefore, we will focus on Pierre Bourdieu's concept of cultural capital in the reference to Marx's legacy. It is important to note that this concept is based on a "takeover" of a term that is commonly considered - since Marx - as strictly economic. The capital in Marx's opus magnum became not only a tool to analyze economic systems but also a catchword and a proper name - a title of one of the most important works in the 19th century (Marx 1976). Arguably, after the analysis of the forms of commodity trade, commodity fetishism, surplus value, and the law of capital accumulation, capitalism as a system got its self-consciousness. Hence, we 
could say, regardless of political system, we are living in the horizon of modernity depicted by Marx's network of concepts. And one of the crucial terms within this framework is "capital" which is nowadays used in many contexts and non-economic meanings as not solely cultural, but also social capital, human capital, creative capital, emotional, intellectual, symbolic or moral (Tittenbrun 2014).

I argue that there might be two alternative (but not opposite) explanations of the omnipresence of this specific term. The first interpretation says: we are witnessing a comprehensive economization of social reality, that means the dependence of different fields to a logic of narrowly and literally understood economic interest ("money rules the world"). This is a kind of mechanistic explanation. However, we can think more dialectically about our modern, capitalistic life subsumed under capital which produces our world and universe of values (Lazzarato 2004). Then, the economy becomes the essence of the social. In other words, the economization of the cultural sphere results from the extension of the sense of economy to the symbolic dimension. And this is how Bourdieu approaches this topic. He postulates the elaboration of general economy of practices as a science of satisfying the needs concerning not only materialistic (as classic political economy does) but also non-materialistic ones such as prestige, power and recognition (Bourdieu 2013). In both cases, economy loses its neutral status and objective legitimization disclosing dependence on the political decisions. We can recognise this situation as the kind of Marx's revenge.

\section{Capital in the Age of Capitalism}

First of all, in this text we are trying to omit a complex problem of the relation between the omnipresence of this concept and the logic of late capitalism (see: J ameson 1991). This issue is too broad and in the need of problematization, we cannot settle it in this place. Undoubtedly, the 
predominant presence of the term "capital" in the discourse of social sciences, and broadly in the public discourse, is related to Marxian diagnosis of capitalism as a cultural formation, which reached maturity in the time of industrial revolution, and created a social model, which one calls modern. Undoubtedly, we can assume that social sciences are more or less consciously steeped in Marx's concept of capital: "a key concept that allows us to capture the quasi-totality of social dynamic under capitalism (but not necessarily to explain all social phenomena)". Marx tries to explore "the genealogy and structure of capital as an epistemological category, and to partially disclose its cognitive strength and vigor" (Kozłowski 2017, p. 22). But like the author admits "it would be a great irony if this splendid category would cease to apply to the realm for which it has been conceived - capitalist economy" (Ibidem). The present article takes for granted this ironic perspective: there is no such thing as a capitalist economy beyond society. According to Marx, capitalist society is constituted as a totality that not only stands opposed to the individuals but also tends to subsume them: they become "mere organs" of the whole.

Capitalism for Marx, as for Weber, is not equivalent to market economy and cannot be reduced only to the economic sphere of capitalist production and exchange (Boltanski, Chiapello 2018). It constitutes the whole system producing an effect of society, cultural patterns and mentality, and which is called after Weber the "spirit" of capitalism, and after Marx - "political economy" (Weber 2005; Marx 1976). The critical perspective of political economy produces a new paradigm of thinking about capitalism as a historically mutable cultural formation, which should be studied in a fusion of such sciences like historiography, economics, sociology, and culture studies.

Moreover, we can treat political economy as a contemporary paraphrase of Aristotelian Politics (1999), and the founding moment of science (or scientific reflexivity) about the modern world. This world is, in 
contrast to the ancient world, built upon blurring the border between private (economic) and public (political) sphere. Economic determinism and political freedom (freedom from life necessities as Hannah Arendt would say) interfering each other, and what constitutes the paradoxical nature of modernity (Arendt 1958). The paradox means that two motions overlap. On one hand, we are witnessing an obliteration of the boundary between politics and economy: it is well seen in Hegel's notion of "civil society" linking the citizenship and effects of the division of labor (Hegel 2001) and the notion of political economy as such. Every economy was a political science until Alfred Marshall wrote Principles of Economics (1890) founding a neoclassical paradigm. Therefore, on the other hand, one of the most characteristic features of late modern discourse is a de-politicization of the economic sphere. It means a narration that economic laws based on a bare economic interest (measurable profit) would belong to a sphere of objective facts, so a sphere immune to political (ideological) attempts. It is worth recalling that after the 2008 crisis, this narrative became the subject of intense criticism (Vogl 2015; Boltanski, Chiapello 2018).

Clearly, economy and politics are two separate concepts: the first refers to the logic of wealth based on the quantity difference (more/ less) and the second to the logic of sovereign power referring to quality differences between being a citizen or not, having a right to happiness or not. Additionally, there is a third logic of moral values fixed to a basic distinction between good and bad which in the language of economics is equal to being more/less valuable. However, capitalism, as Marx showed, is a system of absolute and inalienable equivalence (exchangeability) of these logics. It needs a quality difference between use value of things (non-material as well as meaningful ideas or actions) to change human labor products into commodity, and to generate exchange value, in which the money is expressing the quantity difference. We can say that in the logic of late capitalism money became a symbol 
of liquid modern life thus one principle rules the whole global world: more means better (see: Markowska 2018).

Marx's Capital: Economic or Non-economic Concept?

Before we move to the analysis of Bourdieu's concept of cultural capital, let us briefly consider the most important arguments for non-economical interpretation of the Marxian idea of capital. Wherein we treat Marx as a philosopher who worked on concepts but not a theorist of economy (Kołakowski 1988). As we remember, for Marx the only source of production of value is human labor. Whereas, the power of creating value depends on the expenditure of concrete and unique time of existence. Labor treated as a commodity undergoes a specific split. On one hand, it states a process of creating the use value, a process considered qualitatively in terms of what we produce. On the other, it is considered as exchange value, so it is calculated on the basis of time that is socially necessary to perform a given activity (abstract time). According to Marx capital feeds on the contradiction between concrete and abstract time, between living labor and dead (socially accumulated). A workers who sell own labor on the market, sell their lifetime (qualitatively unique value) and things what could be created in this time. Products of their work - labor socially established as a production process - do not belong to them same as a surplus value which is an effect of this process.

The essence of capital is its antagonistic and alienating attitudetowards the living labor of a worker, which produces the use value of a given product. „This power of preserving value and creating new value is therefore capital's power, and the process appears as one of capital's self-valorization, while the worker who creates the value - value alien to him - is on the contrary impoverished" (Marks 2010, p. 397). The above passage shows that living labor has a tendency to run out and that is why it is a source of exploitation. This finiteness and uniqueness of 
living labor creates the relative additional value, which the capitalist production system needs to generate profit.

According to Marx, only concrete time that is put into labor creates real value - capitalized labor, the power of capital is only maintaining it and multiplying. To put it in other words, in the work process, goods purchased by the capitalist as means of production become once again material components of a new product. This insane and uncontrolled capital productivity, which reaches beyond the designated point of an end of production, is possible only by means of transforming concrete time into abstract time.

"Unlike the measure of material wealth, which is a function of the quantity and quality of particular goods, then, the measure of value expresses a determinate relation-namely, a relation between the particular and the abstract-general that has the form of a relation between moment and totality. Both terms of this relation are constituted by labor functioning as a productive activity and as a socially mediating activity. This double character of labor underlies the quasi-objective, abstract temporal measure of social wealth in capitalism" (Postone 1993, p.191).

The time of multiplying value in separation of specific activity, which, thanks to global market expansion, exchangevalueand networking, has become the dominant time in late capitalism. In this contemporary interpretation, Marx's capital in general can be understood as a special form of time regulation, its abstracting, or virtualization, characterizes the alienating power of social relations.

Likewise, the social aspect of capital was highlighted and explained by Marx in his preliminary inquiring in The Communist Manifesto: "To be a capitalist is to have not only a purely personal but a social status in production. Capital is a collective product, and only by the united action of many members, nay, in the last resort, only by the united action of all members of society, can it be set in motion. Capital is, therefore, not a personal, it is a social power" (1967, p. 97). In this understanding of 
capital, we can say, that it is a meta-relation determining the shape of the social world in which deterioration becomes the condition of potential capitalization of any resource. "It is in this sense that capital is a „social relationship" (Capital, 998) that it thus permeates the social world. I want to suggest that” - like Beasley-Murray writes - „exactly the same proces of valorization, determined by a specific contradiction between concrete time and abstract time, constitutes cultural capital. Cultural capital arises from the fact that only a certain proportion of the activities that makes up the concrete time of use value are valorized by the agents of cultural accreditation" (2000, p. 111).

At this point we are interested only in one thing, whether such an analytical reconstruction of the Marxian notion of capital as a social power or time (in isolation from its strictly economic connotations) will contribute to our understanding of the functioning of a category of cultural capital at Bourdieu's theory.

Marx-Bourdieu: Elective Affinities

Now, we would like to investigate the complex impact of Marx theory on the concept of Bourdieu's capital and its "reflexive" consequences. They are manifested by a strong resistance to Marxian economism reduced to a domination of economy field over cultural values (comp. base/ superstructure) ${ }^{1}$. The one of the purposes of this article is to render such a dichotomy redundant.

Obviously, Bourdieu was influenced by Marx. As we have already mentioned, Pierre Bourdieu is the author of the concept of cultural capital, which - elaborated over the years - played a very important role in his work. Until today, this category is treated as one of the key elements in

' Economism is a term in Marxist discourse. It was used by Lenin in his attacks on Karl Kautsky and the Social Democratic Party of late 19th and early 2oth century Germany, https://en.wikipedia.org/wiki/Economism [access 17.01.2019]. 
critical theory, indicating the cultural character of class inequalities, developed especially in Anglo-Saxon thought (Lamont, Lareau 1988; Fowler 1997; Bennett et al. 2009). A similar thought is developed by Polish researchers who are trying to adopt the category of cultural capital to the Polish context and specificity of Central and East Europe (Zarycki 2008; Gdula, Sadura 2012). What is characteristic of even these analyses that referred to Bourdieu's conceptual apparatus, is they left the Marxian heritage in the shadows. However, in the world of sociology, Marx's direct influence on Bourdieu's idea of capital has been repeatedly emphasized and taken to a theoretical elaboration (BeasleyMurray 2000; Burawoy, Holdt 2012; Tittenbrun 2017; Markowska 2017). According to a popular narration Bourdieu extends Marx using the extra-economic notion of capital (Swartz 1997; Fowler 2011; Desan 2013). But, whether in the light of the fact that Bourdieu has "operationalized" the notion of capital and extended its application, can we call him a Marxist? Not necessarily.

The common interpretation of Bourdieu's relationship to Marxism claims that he transcends Marxism's narrow economism by extending its critical problem beyond the economic sphere and into the cultural and symbolic spheres. "Indeed, Bourdieu rarely missed an opportunity to criticize Marxism for its supposed economic reductionism and substantialism. Moreover [...] he oriented himself against thekind of Marxism that was fashionable in postwar France, in either its Sartrean or Athusserian forms (Fowler 2011). So, although there is no denying that Bourdieu was a close and appreciative reader of Marx, his relationship to Marxism remains ambivalent" (Desan 2013, p. 318). For Mathieu Desan, the concept of capital is central to both Bourdieu and Marx but "the articulation of Bourdieu's notion of capital became problematic precisely as Bourdieu defined it in terms that evokes Marx, albeit incorrectly" (Ibidem, p. 319). Thus, his main thesis is very a sophisticated, reversible sentence: "In short, the concepts of cultural and symbolic 
capital are not extensions of an economic capital conceived in a Marxist sense, and the concept of economic capital of which the other capitals are extended forms is not Marxist" (Ibidem, p. 319). At this point, I have to agree with the author. At the end of the article I will try to show why a Bourdieusian cultural capital, having many types and forms, should be treated as symbolic capital in spe, a tool of symbolic power. It remains responsible for imposing a sense of social environment, defining situations and creating a definitive image of the world. Therefore, I propose to think about a main issue: why, for the author of Distinction (who is a perverse heir of Marx), capital turns out into an essential analytical category, without which it is impossible to depict social phenomena in its historical becoming.

Bourdieu-Marx: Beyond Economism

In the intellectual tradition of France, Bourdieu can be called a postMarxist as well as a post-structuralist thinker. The appearance of the prefix "post" means that the relation between Bourdieu and Marx's legacy is ambivalent. The first one is not an uncritical follower of Marxism (more or less "vulgar"), quite the opposite, hevery often allowed himself to make critical remarks about Marx's certain "naivety” when it comes to the existence and functioning of social classes. „The historical success of Marxist theory, the first would-be scientific social theory to have realized itself so fully in the social world, thus helps to bring about a paradoxical situation: the theory of the social world least capable of integrating the theory effect which Marxism has exerted more than any other - nowadays no doubt represents the most powerful obstacle to the progress of the adequate theory of the social world, to which it has, in other times, contributed more than any other" - claimed Pierre Bourdieu in The Social Spaces and the Genesis of Groups (1985, p. 218). 
Moreover, despite very clear similarity to Marx's analysis of the market of symbolic goods, Bourdieu, from the very beginning of his theoretical path, tried to make a certain distinction from Marx. Indeed, this distinction has its own dynamics, which manifests in constraints of development of cultural capital (more broadly: symbolic) as a fundamental concept. From my point of view, it is important to study this relation and its inner coercion. Particularly interesting is the way of functioning a wider project of general theory of economy of practices in which the theory of strictly economic practices is only a special case (Lebaron 2003).

The first attempt to overcome (and transgress) Marxist tradition took place in the Outline of a Theory of Practice [1972], where Bourdieu clearly follows Marxian demand to transcend the opposition between materialism and idealism by means of a broad notion of economy of practice. One can say that "in the spirit of Marx", the author makes a significant shift from materialistic economism to a dimension of the economy of symbolic goods, which is embodied in the term "symbolic capital". This first transformation of capital into a more universal category could be linked with Max Weber's idea of economy of salvation (2010), and which is based on a temporary delay of fulfilment. As he states in the Outline: "Economism knows no other interest than that which capitalism has produced, through a sort of concrete application of abstraction, by establishing a universe of relations between man and man based, as Marx says, on »callous cash payment«. Thus it can find no place in its analyses, still less in its calculations, for the strictly symbolic interest which is occasionally recognized (when too obviously entering into conflict with »interest « in the narrow sense, as in certain forms of nationalism or regionalism) only to be reduced to the irrationality of feeling or passion" (Bourdieu 2013, p. 177).

The domination of economic rationality (or to use Weber's term: instrumental) was an undeniable cultural and social fact characteristic of 
the secularized world of the industrial revolution. Marx unequivocally treated the sphere of economic interest as a naked reality, which is surrounded by symbolic narratives fulfilling the role of ideology imposed by the ruling class. Weber was much subtler. He introduced a division of rationalities considering a different logic of values. From Bourdieu's point of view, one can say that both were wrong in taking a too onesided point of view. The basic argument that appears at the end of the work devoted to the analysis of Kabyle community on the acceptance of the extended meaning of economics and profit which elude narrow economism based on measurable benefits and gains directly from symbolic rates. "In fact, in a universe characterized by the more or less perfect interconvertibility of economic capital (in the narrow sense) and symbolic capital, the economic calculation directing the agents' strategies takes indissociably into account profits and losses which the narrow definition of economy unconsciously rejects as unthinkable and unnameable, i.e. as economically irrational. In short, contrary to naively idyllic representations of »pre-capitalist« societies (or of the »cultural « sphere of capitalist societies), practice never ceases to conform to economic calculation even when it gives every appearance of disinterestedness by departing from the logic of interested calculation (in the narrow sense) and playing for stakes that are non-material and not easily quantified" (Ibidem 2013, p. 177).

In this essential passage the author argues that for capitalism described by Marx, it is characteristic that economic (materialistic) capital and symbolic (non-materialistic) capital are separated, with the assumption of absolute equivalence between the material and non-material. Which would in fact mean the possibility of conversion of one capital into another. This is the assumption revealed directly in the initial parts of The Communist Manifesto, that the bourgeois revolution consists in the fact that the world is governed by a "naked interest" (economic profit) which in some way destroys the importance of "feudal games" 
based on selflessness and honor and attachment to tradition. "All that is solid melts into air, all that is holy is profaned, and man is at last compelled to face with sober senses, his real conditions of life, and his relations with his kind" (Marx, Engels 1967, p. 83). And here Bourdieu criticizes Marx and Marxian tradition for confusing "things of logic with a logic of things" (2008, p. 40). He states that there exists only one (double or dual) bookkeeping for symbolic goods. Its duality is based on the time dissolution of two types of exchange: immediate (economic contract) and postponed (exchange of gifts). Let us add, that Bourdieu means traditional (pre-capitalist) societies, in which the exchange is a total fact, i.e. it has a symbolic and economic dimension, and symbolic capital is built by the tribal community.

At this point Bourdieu speaks like an anthropologist, and one can say that the modern world is also seen through an anthropologist's glasses: he believes that the dominance of narrowly understood economic capital is apparent. According to the author of Distinction (1984), the world of modern rational homo oeconomicus could not be constituted without the producing the world of pure art and disinterestedness. Therefore, what seems most tangible, i.e. profit, becomes elusive, completely changeable, dependent on the context, time strategy and symbolic frame used to articulate it. All games have only one universal stake: symbolic capital.

The disintegration of world unity - typical for modernity - into the universe of science, economy, ethics and art (according to Weber, guided by different logic of values) would not be possible without the Marxian equivalent form of exchange value. This form of value characteristic to commodity form causes qualitatively different things to interact with each other in a ratio of exchange based on quantitative equivalence. The social world persists in unity established on a time differentiated infinite circulation, where every exchange has its own economic sense. At 
the same time, it should be remembered that economy cannot be reduced only to mercantile type of exchange, but is treated as immanent sphere of differentiated forces, and which is realized by the form of cultural pluriversum of values. One can misinterpret this approach as the aforementioned relation between economy (base) and culture (superstructure), accusing Bourdieu of pan-economism (Tittenbrun 2016). While the author of The Forms of Capital proposes to suspend this opposition well-established in the vulgar Marxist tradition, instead creates a key concept of cultural capital. The notion that reveals the mutual entanglement of economy and culture manifests in the general economy of symbolic practices.

Cultural Capital as a Symbolic Capital

"Social world is accumulated history..." Bourdieu 1986, p. 241

The first test of the analytical power of the category of cultural capital was an attempt to apply it to the research on the impact of a reproduction of class divisions in the education system (Bourdieu, Passeron 1990). The research conducted in 1960s together with J ean-ClaudePasseron overthrew many myths about the equalizing role of education and the process of acquiring cultural competences (see: Coleman 1966). It also laid the foundations for the development of the sociology of education and art. Until today in both these sub-disciplines, the concept of cultural capital as symbolic capital (introducing the effect of distinction) is an important reference point, being a source of both a creative continuation (Lamont 1992; Bukowska et al. 2013; Sadura 2018) as well as criticism (Ranciere 1991; Lareau, Weininger 2003; Goldthorpe 2007; Lahire 2013; Tittenbrun 2017). 
The fundamental attempt to develop a coherent theoretical concept of this key category was taken by Bourdieu only after rethinking the empirical wealth contained in the Distinction. It was included in a short essay from 1986 titled The Forms of Capital. The starting point for him was a strong conviction that in order to understand (not mechanically but dynamically) the social world which is an "accumulated history", the notion of capital and accumulation should be reintroduced into the social science vocabulary. Bourdieu clearly indicates that he intentionally introduces the Marxian concept, giving it a modified meaning. The general definition of capital reads as follows:

"Capital is accumulated labor (in its materialized form or its »incorporated «, embodied form) which, when appropriated on a private, i.e., exclusive, basis by agents or groups of agents, enables them to appropriate social energy in the form of reified or living labor" (1986, p. 241).

It is clear that the starting point is the classical Marxian framework. For Marx a capital is a dead (not real) labor, which enables the appropriation of the energy of a living labor (the source of authentic values). In Bourdieu's language capital is the name for this invisible force, which produces the cohesion of social games and its dynamics, based on a double appropriation: acceptance (accumulation) and exclusion (distinction). It also controls the efficiency of activity, stakes setting and achieving. The world where capital works is a part of human history and not a part of nature. It has past, which entails accumulation (transfer in abstract time, and which in another language is called heritage) and produces a basic network of differences and inequalities. He explains: "Capital, which, in its objectified or embodied forms, takes time to accumulate and which, as a potential capacity to produce profits and to reproduce itself in identical or expanded form, contains a tendency to persist in its being, is a force inscribed in the objectivity of things so that everything is not equally possible or impossible" (Bourdieu 1986, p. 241). 
Culture is a field of relations referring to both material and non-material values. We can say that it is an embodiment of former elaborated capital; an effect of past labor inserted in a material formation, which in a form of crystalized value (symbolic force) is set in motion of reproduction. There is a need to be emphasized that the value which capitalizes itself becomes productive. Thus, capital is an active force of appropriation only if it is accompanied by a live, concrete labor connected with "inculcation and assimilation". Furthermore It is a labor on the concrete body with the use of different tools (included a physical force): „Most of the properties of cultural capital can be deduced from the fact that in its fundamental state, it is linked to the body and presupposes embodiment. The accumulation of cultural capital in the embodied state, i.e., in the form of what is called culture, cultivation, Bildung, presupposes a process of embodiment, incorporation, which, insofar as it implies a labor of inculcation and assimilation, costs time, time which must be invested personally by the investor [emphasis BM]. Like the acquisition of a muscular physique or a suntan, it cannot be done at second hand (so that all effects of delegation are ruled out)" (Bourdieu 1986, p. 243).

As the above passage implies, cultural capital works if it absorbs or invests embodied labor. A formation of cultural competences can be capitalized only if social time (an abstract one) was already accumulated by culture and which manifests in a differentiation of relations within a field. Our ability to identify a situation in which we are, and a control of life (which is the immediate effect of cultural capital) does not entirely depend on our will and determination. An equally important component is the ability to appropriate someone else's work, and the making that he or she is working on our individual gain. It is about the ancestors and family traditions, but also it is about the use of objectified capital in a number of social institutions, social contacts and material resources. 
The factor determining which resource is to be activated (by means of effective capital - self multiplying value) is - according to Bourdieu - the entirety of symbolic field, cultural universe. From that point of view, one can say that separated types of capitals like economic, social and cultural (informative) are types of "cultural" capital, that works in the field of economy of symbolic goods. The symbolic form of capital „in whatever form - insofar as it is represented, i.e. apprehended symbolically, in a relationship of knowledge or, more precisely, of misrecognition and recognition, presupposes the intervention of the habitus, as a socially constituted cognitive capacity" (Bourdieu 1986, p. 255). The effectiveness of capital, so the possibility of an alliance between our work and the work of others (in the past, present and future) depends on the ability to recognize complex rules of games in a given field. Hence, the skill of matching strategy of action that enables the conversion of capitals and reinforces the effect of symbolic acknowledgment.

The possibility of conversion of capitals confirms that the difference among them is a functional not substantial difference. In the world of social practices, the basic difference between material and ideal declines. What matters is only what is practical, what enables the goal of recognition and high position in a given field. From the perspective of economy of practices, every practice has an economic character, i.e. is profit-oriented, never pointless, nor selfless. One of the subtlest strategies of gaining profit is, as Bourdieu notices, social production of things/stakes devoid of economic dimension in a narrow meaning. In this sense, the value of disinterested action effectively conceals the "game of interests", which is based on exclusion and exploitation. Thus, Bourdieu's theory of symbolic violence and symbolic capital, to which he returns at the end of his life in Pascalian Meditations, is undoubtedly Marxian:

"Every kind of capital (economic, cultural, social) tends (to different degrees) to function as symbolic capital (so that it might be better to 
speak, in rigorous terms, of the symbolic effects of capital) when it obtains an explicit or practical recognition, that of a habitus structured according to the very structures of the space in which it been engendered. In other words, symbolic capital (male honour in Mediterranean societies, the honourability of the notable or the Chinese mandarin, the prestige of the celebrated writer, etc.) is not a particular kind of capital but what every kind of capital becomes when it is misrecognized as capital, that is, as force, a power or capacity for (actual or potential) exploitation, and therefore recognized as legitimate. More precisely, capital exists and acts as symbolic capital (securing profits - as observed, for example in the maxim 'honesty is the best policy') in its relationship with a habitus predisposed to perceive it as a sign, and as a sign of importance, that is, to know and recognize it on the basis of cognitive structures able and inclined to grant it recognition because they are attuned to what it is. Produced by the transfiguration of a power relation into a sense relation, symbolic capital rescues agents from insignificance, the absence of importance and of meaning" (Bourdieu 2000, p. 242).

Symbolic capital is the general form of capital, just as Marx's exchange value is the general form of value; it enables the conversion of different kinds of capital and produces quantitative and qualitative profit. The statement that symbolic capital transforms power into sense (how the above passage about the validation moment can be interpreted) seems to be relevant. However, after reflection, we must admit that it also means the reverse process, the ability to transform sense into power. Where power means the power of oversight or repression of material conditions of production of sense as a symbolic frame of the world. 
Conclusion

„The mark of the modern world is the imagination of its profiteers and the counter-assertiveness of the oppressed. Exploitation and the refusal to accept exploitation as either inevitable or just constitute the continuing antinomy of the modern era, joined together in a dialectic which has far from reached its climax in the twentieth century."

Finally, we may ask: what general conclusions are coming from the analysis of "capital" as an analytical category? One of them would be to realize that the general science about the economy of cultural practices (or economy of symbolic goods) is in fact political economy in the sense of Marx. Its critical power consists in revealing the basic mechanism of symbolic violence (the method of producing and legitimizing values). Which involves de-politicization of economy, that is establishing the pursuit of material profit (or, more broadly, welfare) as something natural, inscribed in "human nature". It also shows that the autonomy of fields such as science or art makes them also treated as "apolitical" and unrelated to symbolic power. While, as I mentioned earlier, Bourdieu claimed that the distinction between economic and "pure" is needed to generate economic profit, politics - in its broad meaning of symbolic power field - hides its connection to politics - in a narrow sense - to be more effective. It is everywhere and nowhere, dispersed and neutral, hidden behind the authority of science and, above all, the state as a bureaucratic apparatus representing the general interest. In other words, symbolic violence associated with symbolic capital works best in fields that are not directly related to political power.

The second conclusion, even more general, indicates a fact that capitalism understood as an essential condition for the functioning of modern society, is a historical creation in the double sense of this word. It is produced by history, as well as colonizing the past and the future. It 
reproduces "feudal games" based on nostalgia for tradition and "true" values, because they capitalize most effectively the heritage of the past: accumulated labor of past generations. Apparently, we live in society without or beyond history (Debord 2005). This appearance is one of the most cunning masking effects that a capitalist-organized society produces. In fact, what was worked out, accumulated profit in the form of capital works in our favor (whether we like it or not). Thus, to pay back or pay off all the debts in order to cut off the past and overcome the social distinction remains impossible.

References

Arendt H. (1958), The Human Condition, The University of Chicago, Chicago Aristotle (1999), Politics, Batoche Books, Kitchener

Beasley-Murray J. (2000), Value and Capital in Bourdieu and Marx, (in:)

Pierre Bourdieu. Fieldwork in Culture, (Eds.), Brown N., Szeman I., Rowman \& Littlefield Publishers, Lanham-Boulder- New York- Oxford

Bennett T., Savage M., Silva E., WardeA., Gayo-Cal M., Wright D. (2009), Culture, Class, Distinction, Routledge, London

Boltanski L., Chiapello E. (2018), The New Spirit of Capitalism, Verso, London Bourdieu P. (1984), Distinction. A Social Critique of the Judgment of Taste, Harvard University Press, Cambridge

Bourdieu P. (1985) Social Space and the Genesis of Group, (in:) Idem, Social Science Information, SAGE, London- Beverly Hills- New Delhi)

Bourdieu P. (1986), The Forms of Capital, (in) Handbook of Theory and Research for the Sociology of Education, (Ed.) Richardson J.G., Greenwood Press, New York

Bourdieu P., Passeron J-K. (1990), Reproduction in Education, Society and Culture, Sage, London- Thousand Oaks- New Delhi 
Bourdieu P. (1993) The Field of Cultural Production: Essays on Art and Literature, Columbia University Press, New York

Bourdieu P. (2000), Pascalian Meditations, Stanford University Press, Stanford

Bourdieu P. (2013), Outline of a Theory of Practice, Cambridge University Press, Cambridge

Bukowska X., J ewdokimow M., Markowska B., Winiarski P. (2013), Kapitat kulturowy $w$ działaniu [Making a Cultural Capital Work], Collegium Civitas- ISP PAN- UKSW, Warszawa

Burawoy M., Holdt K. (2012), Conversations with Bourdieu. The Johanesburg Moment, Wits University Press, J ohanesburg

Çalışkan K., Callon M. (2009), Economization, part 1: shifting attention from the economy towards processes of economization, "Economy and Society" Vol. 38, Iss. 3, DOI: 10.1080/03085140903020580

Coleman J.S. (1966) Equality of Educational Opportunity, US Office of Education, Washington

Debord G. (2005), Society of the Spectacle, Rebel Press, London

Desan M.H. (2013), Bourdieu, Marx and Capital: A Critique of the Extension Model, "Sociological Theory" Vol. 31, No. 4

Fowler B. (2011), Pierre Bourdieu: Unorthodox Marxist?, (in:) The Legacy of Pierre Bourdieu: Critical Essays, (Eds.) Susen S., Turner B.S., Anthem, London Gdula M., Sadura P. (2012), Style życia i porzadek klasowy $w$ Polsce [Lifestyle and Class Order in Poland], Scholar, Warsaw

Goldthorpe J.H. (2007), “Cultural Capital”: Some Critical Observations, "Sociologica" Vol. 2

Harrison L.E., Huntington S.P. (2000), Culture Matters: How Values Shape Human Progress, Basic Books, New York

Hegel G.W.F. (2001), Philosophy of Right, Batoche Books, Kitchener J ameson F. (1991), Postmodernism, or The Cultural Logic of Late Capitalism, Duke University Press, Durham

Kołakowski L. (1988), Main Currents of Marxism, Aneks Publishers, London 
Kozłowski M. (2017), Marx's Biggest Idea, or Six Fatures of Capital (On the $150^{\text {th }}$ anniversary of the publication of the first volume of Das Kapital), "Eidos. A J ournal for Philosophy of Culture" Vol. 2

Lahire B. (2013), Dans les plis singuliers du social. Individus, institiutions, socialisations, La Decouverte, Paris

Lamont M. (1992), Money, Morals, Manners: The Culture of the French and American Upper-Middle Class, University of Chicago Press, Chicago

Lamont M., Lareau A. (1988), Cultural capital: Allusions, gaps and glissandos in recent theoretical developments, "Sociological Theory" Vol. 6, No. 2

Lareau A., Weininger E.B. (2003), Cultural capital in educational research: A critical assessment, "Theory and Society" Vol. 32, No. 5/ 6

Lazzarato M. (2004), From Capital-Labour to Capital-Life, "ephemera" Vol. 4, No. 3

Lebaron F. (2003), Pierre Bourdieu: Economic Models against Economism, “Theory and Society" Vol. 32, Iss. 5-6

Markowska B. (2017), Either Capital or Class...., "Przegląd socjologiczny", Vol. LXVI, Iss. 4, DOI: 10.26485/ PS/ 2017/66.4/ 8

Markowska B. (2018), Homo Libidinous and the Economy of Desire: Rereading Simmel's The Philosophy of Money after Freud, "Polish Sociological Review”Vol. 4, No. 204, DOI: 10.26412/psr204.05

Marx K. (1976), Capital. A Critique of Political Economy, Vol. 1, Penguin Books, London

Marx K. (2010), Results of the Direct Production Process, (in:) Marx K., Engels F., Collected Works, Vol. 34 Marx 1861-64, Lawrence \& Wishart, Electric Book, Chadwell Heath

Marx K, Engels F. (1967), The Communist Manifesto, Penguin Books, London-New York

Moore R. (2008), Capital, (in) Pierre Bourdieu: Key Concepts, (Ed.) Grenfell M., Acumen, Durham

Postone M. (1993), Time, Labour, and Social Domination: A Reinterpretation of Marx's Critical Theory, Cambridge University Press, Cambridge 
Ranciere J . (1991), The Ignorant Schoolmaster, Stanford University Press, Stanford

Sadura P. (2018), Państwo, szkoła, klasy [State, School, Classes], Wydawnictwo Krytyki Politycznej, Warsaw

Silva E., Warde A. (2010), Cultural Analysis and Bourdieu's Legacy, Routledge, London- NewYork

Swartz D. (1997), Culture\&Power. The Sociology of Pierre Bourdieu, The University of Chicago Press, Chicago

Tittenbrun J . (2014), Concepts of Capital: The commodification of social life, Transaction Publishers, New Brunswick-NewJ ersey

Tittenbrun J . (2016), Concepts of capital in Pierre Bourdieu's theory, "Miscellanea Anthropologica et Sociologica" Vol. 17, No. 1

Tittenbrun J . (2017), Neither capital nor class. A critical analysis of Pierre Bourdieu's theoretical framework, Vernon Press, Wilmington

Vogl J . (2015), The Spectre of Capital, Stanford University Press, Stanford

Wallerstein I. (1974) The Modern World-System, vol. 1, Academic Press, New York

Weber M. (2005), The Protestant Ethics and the Spirit of Capitalism, Routledge, London- NewYork

Zelizer V.E. (2011), Economic Lives. How Culture Shapes Economy, Princeton University Press, Princeton- Oxford

This article is a translated and modified version of the text that was published in the previous issue of "Zoon Politikon". See: Barbara Markowska, Kapitał jako kategoria analityczna: Marks-Bourdieu, "Zoon Politikon" (6) 2015, DOI: $10.19247 / Z O O N 201512$. 